\title{
PECULIARITIES OF DEVELOPMENT AND EFFICIENCY OF TRANSPORT INFRASTRUCTURE USAGE IN THE COUNTRIES OF ECONOMIC COOPERATION ORGANIZATION (ECO)
}

\author{
O.O.Bilovska \\ Associate professor of the department of tourist business and regional studies \\ of V. Karazin Kharkov National University \\ o.bilovska@karazin.ua \\ O.V.Khanova \\ Associate professor of the department of international economic relations \\ of V. Karazin Kharkov National University \\ e.v.khanova@karazin.ua
}

\begin{abstract}
The article considers peculiarities of development and efficiency of transportusage infrastructure in the countries of Economic Cooperation Organization (ECO). The research emphasizes the considerable territorial inequality of transport infrastructure development in the considered countries. Estimation of the level of transport infrastructure provision with the help of Engelcoefficient has proved that the ECO countries which are best provided with railroad infrastructure are Azerbaijan, Kazakhstan and Turkmenistan, and the least provided countries are Kyrgyzstan, Tajikistan and Pakistan. The author identidies the basic goal and task of the transport logistics. Analysis of efficiency of transport infrastructure functioning in the countries as well the level of their integration in the world transport system has been carried out via index of transport logistics efficiency within the period of $2007-2016$.
\end{abstract}

Key words: transport infrastructure, Economic Cooperation Organization(ECO), transport logistics, transport logistics efficiency index.

\section{ОСОБЛИВОСТІ РОЗВИТКУ ТА ЕФЕКТИВНОСТІ ВИКОРИСТАННЯ ТРАНСПОРТНОЇ ІНФРАСТРУКТУРИ} В КРАЇНАХ ОРГАНІЗАЦІЇ ЕКОНОМІЧНОГО СПІВРОБІТНИЦТВА (ОЕС)

У статті розглянуті особливості розвитку та ефективності використання транспортної інфрраструктури в країнах організації економічного співробітництва (OEC). Акцентовано увагу на значній територіальній диференціації розвитку транспортної інфраструктури в досліджуваних країнах. Розрахунок ступеню забезпеченості транспортною інфраструктурою за допомогою коефіцієнта Енгеля довів, що найбільш забезпеченими залізничною інфраструктурою серед країн ОЕС є Азербайджан, Казахстан та Туркменістан, найменш забезпеченою - Киргизстан, Таджикистан та Пакистан. Визначено основну мету та завдання транспортної логістики. Проведено аналіз ефективності функціонування транспортної інфраструктури в країнах та ступеню їх інтеграції у світову транспортну систему через індекс ефективності транспортної логістики за період з 2007 по 2016 рр.

Ключові слова: транспортна інфрраструктура, Організація економічного співробітництва (OEC), транспортна логістика, індекс ефективності транспортної логістики.

ОСОБЕННОСТИ РАЗВИТИЯ И ЭФФЕКТИВНОСТИ ИСПОЛЬЗОВАНИЯ ТРАНСПОРТНОЙ ИНФРАСТРУКТУРЫ В СТРАНАХ ОРГАНИЗАЦИИ ЭКОНОМИЧЕСКОГО СОТРУДНИЧЕСТВА (ОЭС)

В статье рассмотрены особенности развития и эффективности использования транспортной инфраструктуры в странах организации экономического сотрудничества (ОЭС). Акцентировано внимание на значительной территориальной дифференциации развития транспортной инфраструктуры в исследуемых странах. Расчет степени обеспеченности транспортной инфраструктурой с помощью коэффициента Энгеля доказал, что наиболее обеспеченными железнодорожной инфраструктурой среди стран ОЭС являются Азербайджан, Казахстан и Туркменистан, наименее обеспеченными - Киргизстан, Таджикистан и Пакистан. Определена основная цель и задание транспортной логистики. Проведен анализ эффективности функционирования транспортной инфраструктуры в странах и степени их интеграции в мировую транспортную систему через индекс эффективности транспортной логистики за период с 2007 по 2016 гг.

Ключевые слова: транспортная инфраструктура, Организация экономического сотрудничества (ОЭС), транспортная логистика, индекс эффективности транспортной логистики.

Problem statement. Transport infrastructure is one of important components ofthe world economy and along with thedistribution, production and warehousing logisticshas clear territorial inequality and requires further studies to identify spatial imbalance of logistics development and search for opportunities oflinks optimization etc.

Analysis of recent studies and published works. The problem of logistics development and in particular transport logistics has been studied in the works of the following national and foreign scientists: D. Bowersox,
D. Kloss, D. Lambert, S. Langley, K.Melzer, E.Schneider, M.Danko, V. Zubenko, T. Maselko, A. Novikova, O. Palant, V. Pankratov, K. Pluzhnikov, N. Polyanska, I. Semenenko, V. Sergeev, I. Smirnov, N. Shapoval.

The objective of the article is identification of peculiarities of development and efficiency of transport infrastructure usage in the countries of Economic Cooperation Organization (ECO).

Statement of the basic material. Economic Cooperation Organization - (ECO) is intergovernmental organization, members of which are seven Asian 
and three Eurasian countries. Organization functions as a platform for discussion of ways of enhancing of trade and investment opportunities of ECO member countries. ECO is a special organization according to the United Nations Charter [1]. Its overall goal is creation of common market of goods and services similar to the European Union. Atthe present stage of the world economy development the role of infrastructure increases considerably as a factor which shapes functioning and development of the whole economy. Infrastructure is central to the structure of the whole reproduction process as a result of using a considerable part of investment and labor resources; it facilitates further social and international division of labor, enhancement of integration process in the world economy[2].Functioning of the world economy of transport services is characterized by high intensity. This can be explained by the fact that one foreign trade agreement, especially largescale, is rarely accompanied by closing one transport agreement because its actualization is often carried out by several mediators and transporters with different means of transport and of different nationality [3]. Air network is a complex of interrelated air routes and elements of air infrastructure which functions with the aim to provide the most rational satisfaction of needs of economy and populationfor fast long-distancetransportation [4, p. 8].

In table1dynamics of air traffic cargo turnover in ECO countries has been provided.

Dynamics of air traffic cargo turnover in ECO countries,mln.tons $/ \mathbf{k m}$

\begin{tabular}{|l|c|c|c|c|c|c|}
\hline & 2010 & 2011 & 2012 & 2013 & 2014 & 2015 \\
\hline Afghanistan & 108 & 109 & 117 & 85 & 34 & 33 \\
\hline Azerbaijan & 8 & 10 & 13 & 8 & 31 & 42 \\
\hline Iran & 97 & 86 & 66 & 84 & 108 & 107 \\
\hline Kazakhstan & 42 & 51 & 54 & 58 & 45 & 28 \\
\hline Pakistan & 333 & 298 & 286 & 293 & 205 & 183 \\
\hline Turkey & 1149 & 1544 & 1934 & 2296 & 2630 & 2882 \\
\hline Uzbekistan & 154 & 154 & 111 & 99 & 110 & 114 \\
\hline
\end{tabular}

Source: created by authorsafter [5]

In Fig.1average cargo turnover of air traffic within the period 2010-2015 has been provided.

The largest cargo turnover can be seen in Turkey;all the other countries have more than 10 times lower volume of cargo transportation by air transport.

In Table 2 data on dynamics of air transport passenger turnover in ECO countries has been provided.

In Fig. 2 average passenger turnover of air transport within the period 2010 - 2015 has been provided.

The largest passenger turnover can be seen in Turkey; all the other countries have more than 10 times lower volume of passenger traffic by air transport.

Railway transport is type of rail transport which conducts transportation of passengers and cargo in wheel vehicles which run on rails. Railway transport is a branch of industry, part of traffic network of logistic chains, which enhances international trade and economic growth. The main components of railway transport are:

- material component(the railway itself), which is divided into a) infrastructure: rail track and artificial modules (bridges, tunnels, railway stations, stations, depot), devices of signaling, centralization and blocking, trolley system (power supply devices, railway sub-stations);b) rolling equipment: traction electrical equipment (locomotive engine) and no traction electrical equipment (cars) - rail cars and coach cars;

- operational component, which is divided into a) technical operation - dispatching control, development of optimum ways of managing transportation process;b) commercial operation - relations with cargo shippers / receivers / owners and passengers [6].

In table 3dynamics of railway transport cargo turnoverin ECO countries has been provided.

Table 2

Dynamics of passenger turnover in ECO countries, mln. passengers

\begin{tabular}{|l|c|c|c|c|c|c|}
\hline & 2010 & 2011 & 2012 & 2013 & 2014 & 2015 \\
\hline Afghanistan & 1,9 & 2,2 & 1,7 & 2 & 2,2 & 1,9 \\
\hline Azerbaijan & 0,7 & 1,3 & 1,5 & 1,6 & 1,7 & 1,8 \\
\hline Iran & 3 & 3,7 & 4 & 4,7 & 4,9 & 5 \\
\hline Kazakhstan & 0,3 & 0,5 & 0,4 & 0,7 & 0,7 & 0,6 \\
\hline Pakistan & 6,5 & 7,9 & 7,9 & 7,8 & 7,6 & 8,4 \\
\hline Turkey & 0,06 & 0,8 & 0,6 & 0,6 & 0,7 & 0,8 \\
\hline Uzbekistan & 45,6 & 53,5 & 63,3 & 74,4 & 84,5 & 96,6 \\
\hline Afghanistan & 0,3 & 0,1 & 0,1 & 1,8 & 1,7 & 2,1 \\
\hline Azerbaijan & 2,1 & 2,2 & 2,5 & 2,6 & 2,5 & 2,4 \\
\hline
\end{tabular}

Source: created by authorsafter[5]

Table 3

Dynamics of railway transport cargo turnover in ECO countries, mln.tons $/ \mathbf{k m}$

\begin{tabular}{|l|c|c|c|c|c|c|}
\hline & 2010 & 2011 & 2012 & 2013 & 2014 & 2015 \\
\hline Afghanistan & 8 & 8 & 7 & 8 & 8 & 8 \\
\hline Azerbaijan & 19 & 20 & 21 & 22 & 22 & 24 \\
\hline Iran & 171 & 213 & 223 & 235,8 & 235,8 & 235,8 \\
\hline Kazakhstan & 0,7 & 0,7 & 0,7 & 0,9 & 0,9 & 0,9 \\
\hline Pakistan & 4 & 6 & 2 & 2 & 2 & 2 \\
\hline Turkey & 0,8 & 0,8 & 0,7 & 0,5 & 0,5 & 0,5 \\
\hline Uzbekistan & 9 & 11 & 10 & 10 & 10 & 11 \\
\hline Afghanistan & 12 & 12 & 12 & 12 & 12 & 12 \\
\hline Azerbaijan & 22 & 22 & 22 & 22 & 22 & 22 \\
\hline
\end{tabular}

Source: created by authorsafter[5]

In Fig. 3 average cargo turnover of railway transport within the period 2010 - 2015 has been provided.

The largest cargo turnover can be seen in Kazakhstan; all the other countries have more than 10 times lower volume of cargo traffic by railway transport. 


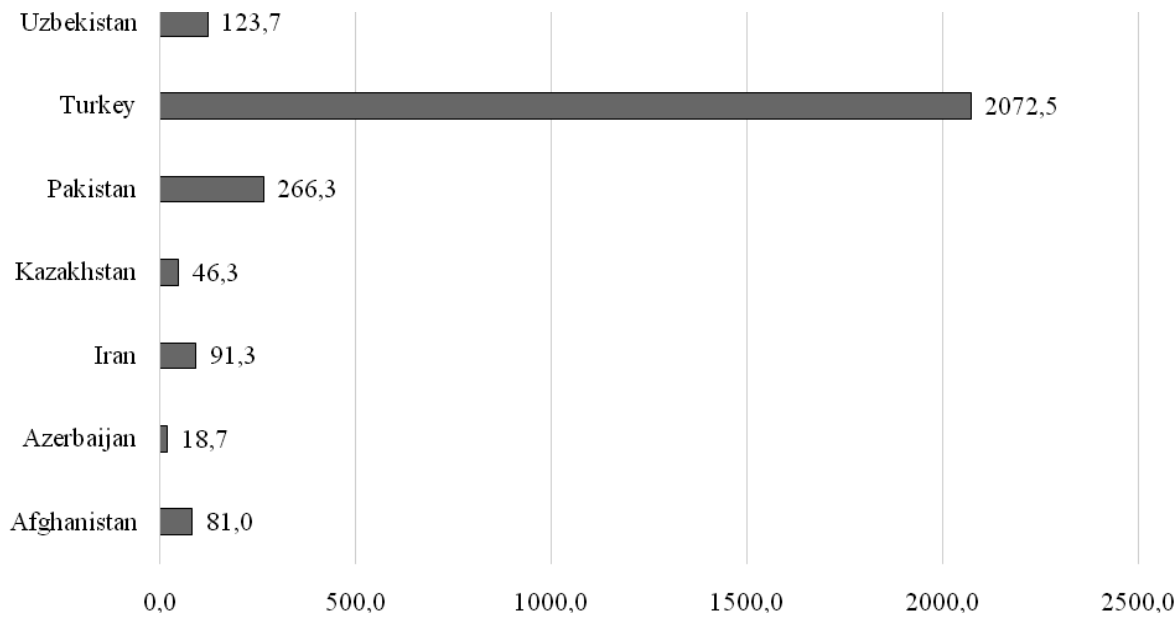

Fig. 1. Annual average cargo turnover, 2010-2015, mln.tons/km. Source: created by authors after [5]

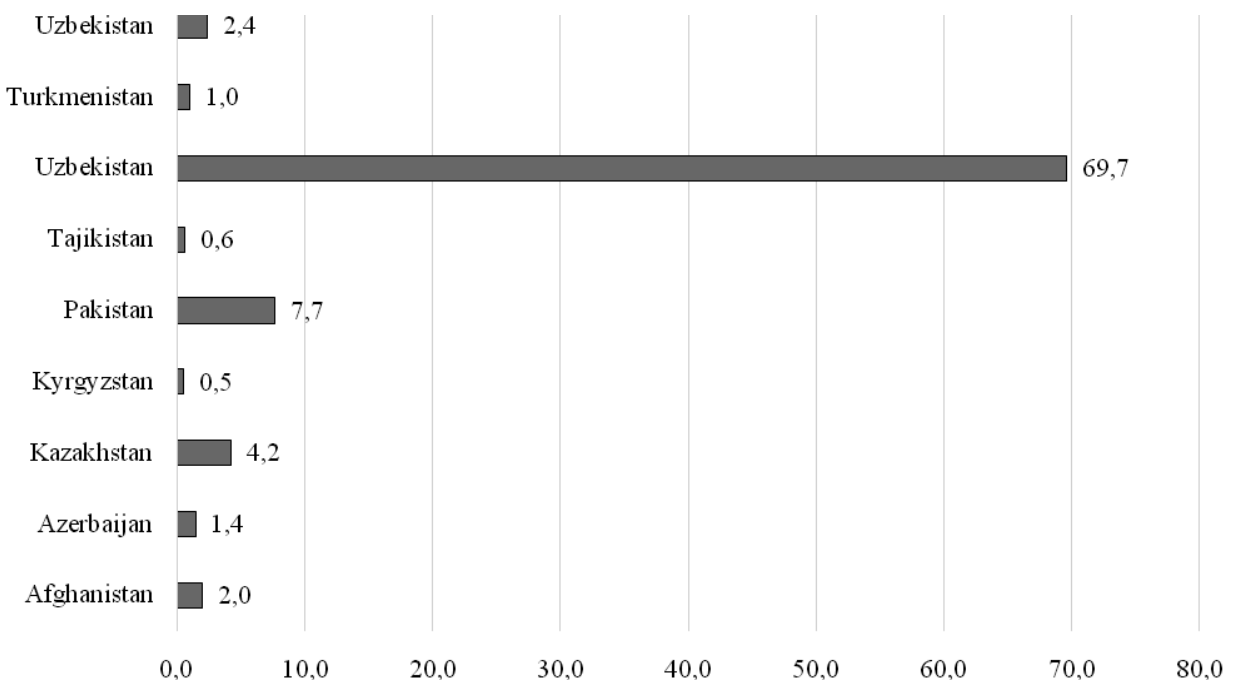

Fig.2. Annual average passenger turnover, 2010-2015, mln. passengers. Source: created by authors after [5]

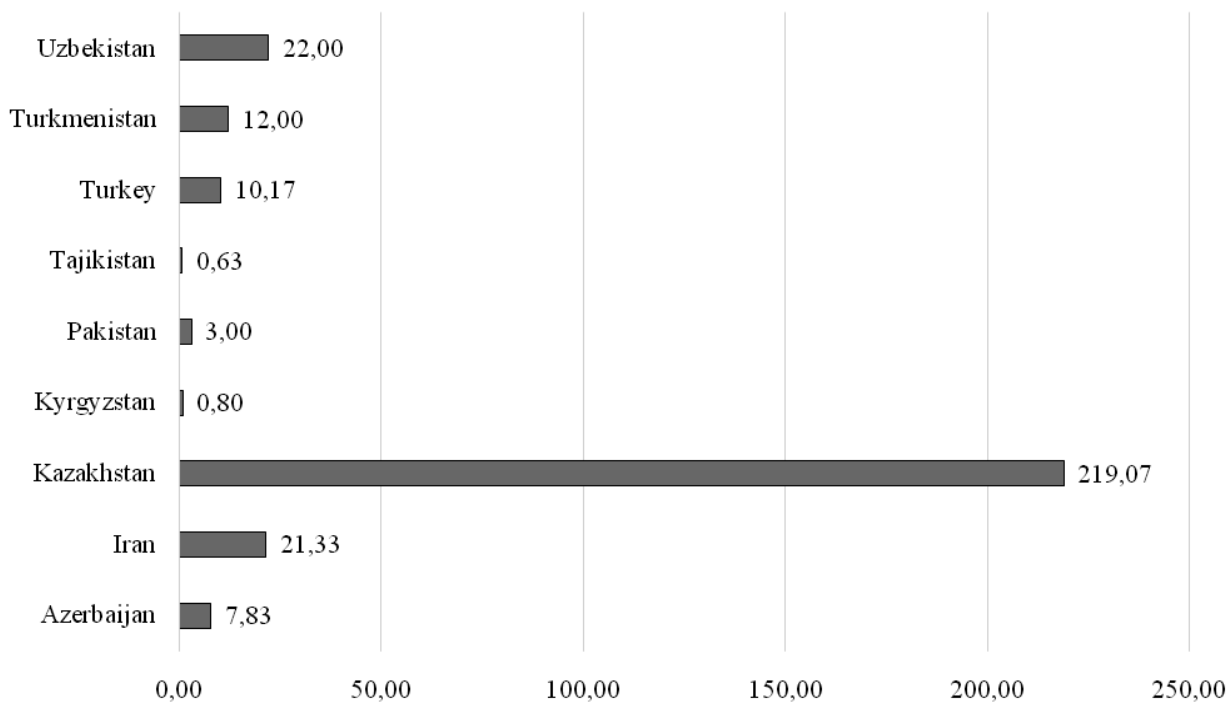

Fig.3. Annual average cargo turnover, 2010-2015, mln.tons/km. Source: created by authors after [5] 


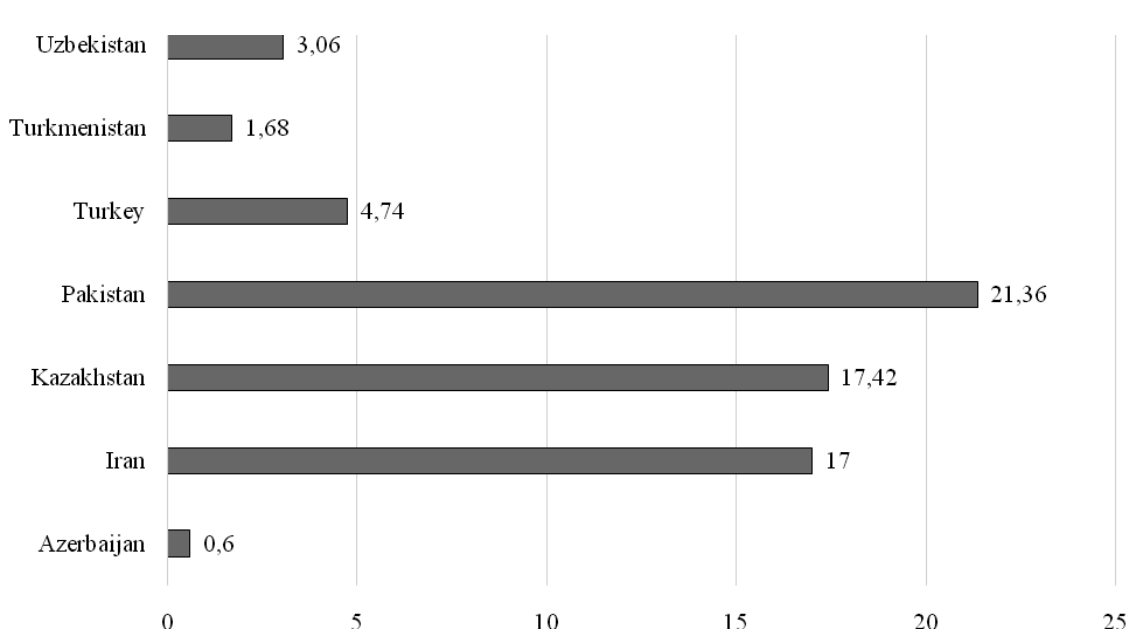

Fig.4. Annual average passenger turnover, 2010-2015, mln. passengers. Source: created by authors after [5]

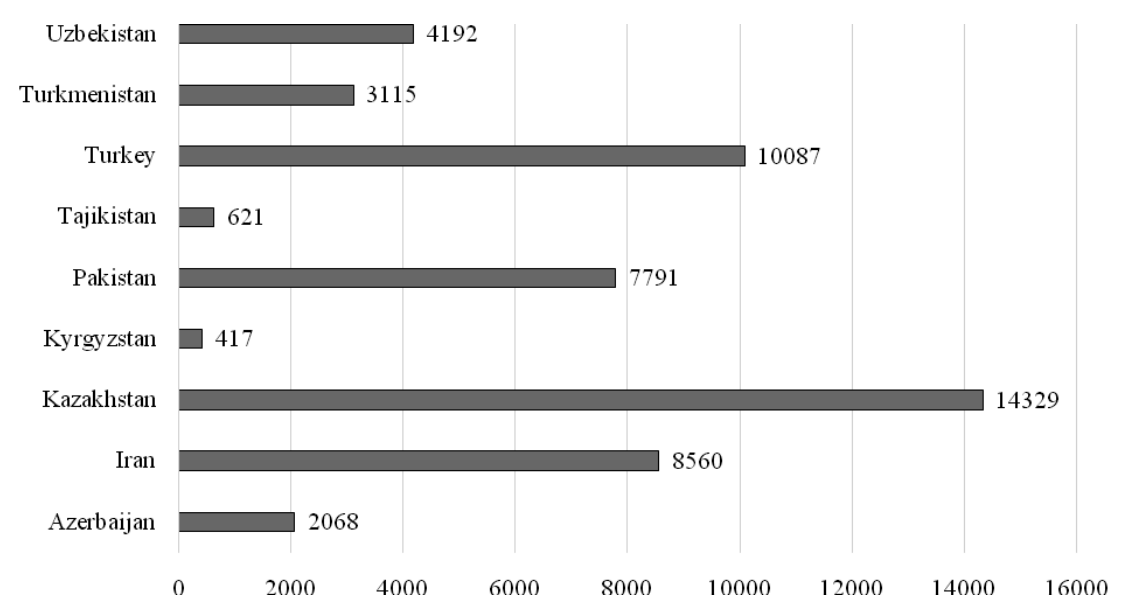

Fig.5. Rail mileage, km, 2015. Source: created by authors after [5]

In Table 4data on dynamics of railway transport passenger turnoverin ECO countries has been provided.

Table 4 Dynamics of railway transport passenger turnover in ECO countries, mln. passengers

\begin{tabular}{|l|c|c|c|c|c|}
\hline & 2010 & 2011 & 2012 & 2013 & 2014 \\
\hline Afghanistan & 0,9 & 0,6 & 0,5 & 0,5 & 0,5 \\
\hline Azerbaijan & 16,8 & 17,8 & 17,1 & 17,1 & 16,2 \\
\hline Iran & 15,4 & 16,5 & 18,4 & 18,4 & 18,4 \\
\hline Kazakhstan & 24,4 & 20,6 & 20,6 & 20,6 & 20,6 \\
\hline Pakistan & 5,4 & 5,8 & 4,5 & 3,7 & 4,3 \\
\hline Turkey & 1,2 & 1,8 & 1,8 & 1,8 & 1,8 \\
\hline Uzbekistan & 2,9 & 3 & 3 & 3 & 3,4 \\
\hline
\end{tabular}

Source: created by authors after [5]

In Fig.4 average railway transport passenger turnover within the period 2010 - 2014 has been provided.
The largest railway transport passenger turnover can be seen in Pakistan, Kazakhstan and Iran; all the other countries have more than 10 times lower volume of passenger traffic by railway transport.

Total rail mileage has been provided in Fig.5.

As one can see in the Fig. 5 the longest rail mileage can be observed in Kazakhstan, Turkey, Iran and Pakistan, and the lowest rail mileage can be observed in Tajikistan and Kyrgyzstan.

However the total rail mileage is not informative indicator,that is why the level oftransport infrastructure provision has been calculated by us it can be defined with the help of Engel coefficient $\left(\partial_{e}\right)$, Fig. 6:

$$
\partial_{e}=\frac{L}{\sqrt{S H}},
$$

where $L-$ the length of the road; $S$ - square footage; $H$ - population size. 
According to the results of the calculation the highest level of transport infrastructure provision in the ECO countries can be seen in Azerbaijan, Kazakhstan and Turkmenistan, the lowest level of transport infrastructure provision can be seen in Kyrgyzstan, Tajikistan and Pakistan.

In terms of volume of transported cargo, motor transport exceeds the other means of transport, but its cargo turnover is lower than the one of railway and sea transport. In Fig.7density of road traffic routes in the ECO countries has been provided.
As one can see in the Fig. 7, the highest density of road traffic routes can be observed in Turkey and Pakistan. Such countries as Turkmenistan, Kazakhstan and Kyrgyzstan do not have dense system of road traffic routes.

Logistics is skillful and optimum organization of cargo delivery and is a result of using transport infrastructure. Virtually any business which is in any way concerned with the necessity of cargo delivery: goods, raw materials, materials, components etc. In many cases the cost of such delivery takes up a considerable part

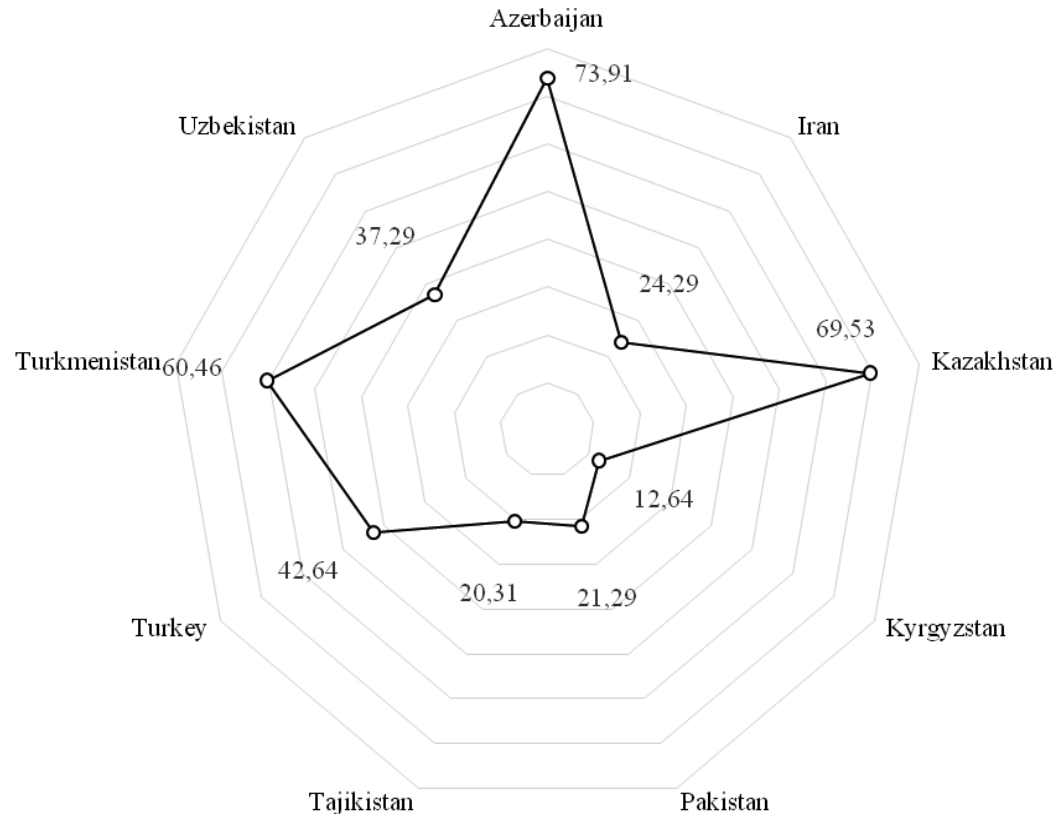

Fig.6. The level of transport infrastructure provision of ECO countries2015. Source: created by authors after [5]

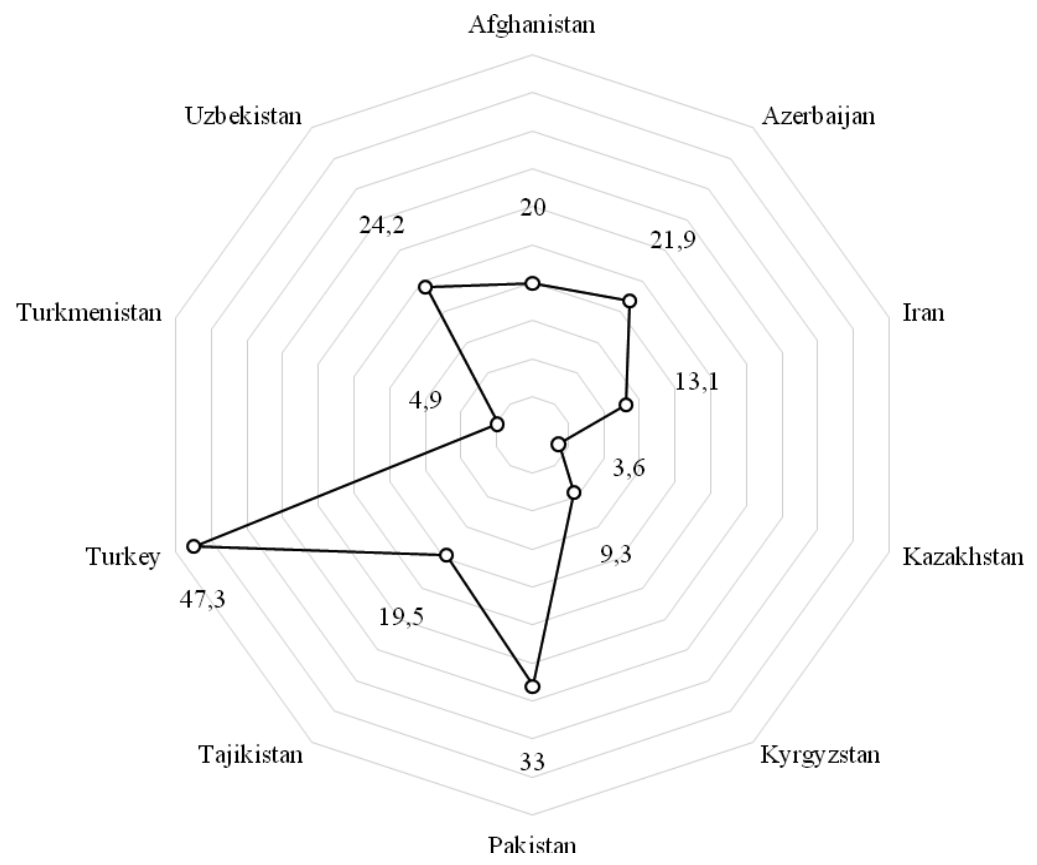

Fig. 7. Density of road traffic routes in ECO countries, $\mathrm{km} / \mathrm{km}^{2}, 2015$. Source: created by authors after [5] 
of the total costs of a company, that is why optimization of such costs should be paid considerable attention.

This is the main object which transport logistics has in view. Transport logistics is a complex of measures conducted with the aim of cargo and goods delivery organization with minimum time and financial expenditures. At the time of cargo transportation between countries transport logistics also includes the stages of customs clearance, preparation for this and issuance of all necessary documents. The main tasks include [8]:

a) analysis of dispatching and destination points;

b)analysis of the cargo transported;

c)choice of optimum transport. Another important task of transport logistics should be completed - select optimum type and model of transport for cargo transportation. In case of long distances even several types of transport may be used. For optimum choice of means of transport the following parameters should be taken into account:

- cargo delivery speed (air transport provides the highest speed, sea transport provides the lowest speed, railway and motor transport provide average speed);

- volume and capacity (sea transport provides the maximum volume and capacity, air and railway transport provide high volume and capacity and motor transport provides the lowest volume and capacity);
- cost of transportation (air transport provides the maximum cost, sea transport provides high cost, railway and motor transport provide the lowest cost);

- mobility (motor and air transport provide high mobility, railway and sea transport provide low mobility);

- preservation of cargo (air transport provides the highest level, railway and sea transport provide satisfactory level and motor transport provides lower level);

d) the most convenient route development;

e)control over the process of loading, transportation and discharging of cargo $[9 ; 10]$.

Efficiency of transport infrastructure functioning in a country and the level of its integration into the world transport system is measured with the help of transport logistics efficiency indexes. Let's take a closer look at differentiation of logistics index in the ECO countries.

1. Opportunity to track consignment $(1=$ low to $5=$ high) .

2. Adequacy and quality of logistic services $(1=$ low to $5=$ high).

3. Simplicity of logistic setup at competitive prices $(1=$ low to $5=$ high $)$.

4. Efficiency of customs clearing process $(1=$ low to $5=$ high).

5. Frequency of planned or expected time cargo delivery to the recipient $(1=$ low to $5=$ high $)$.
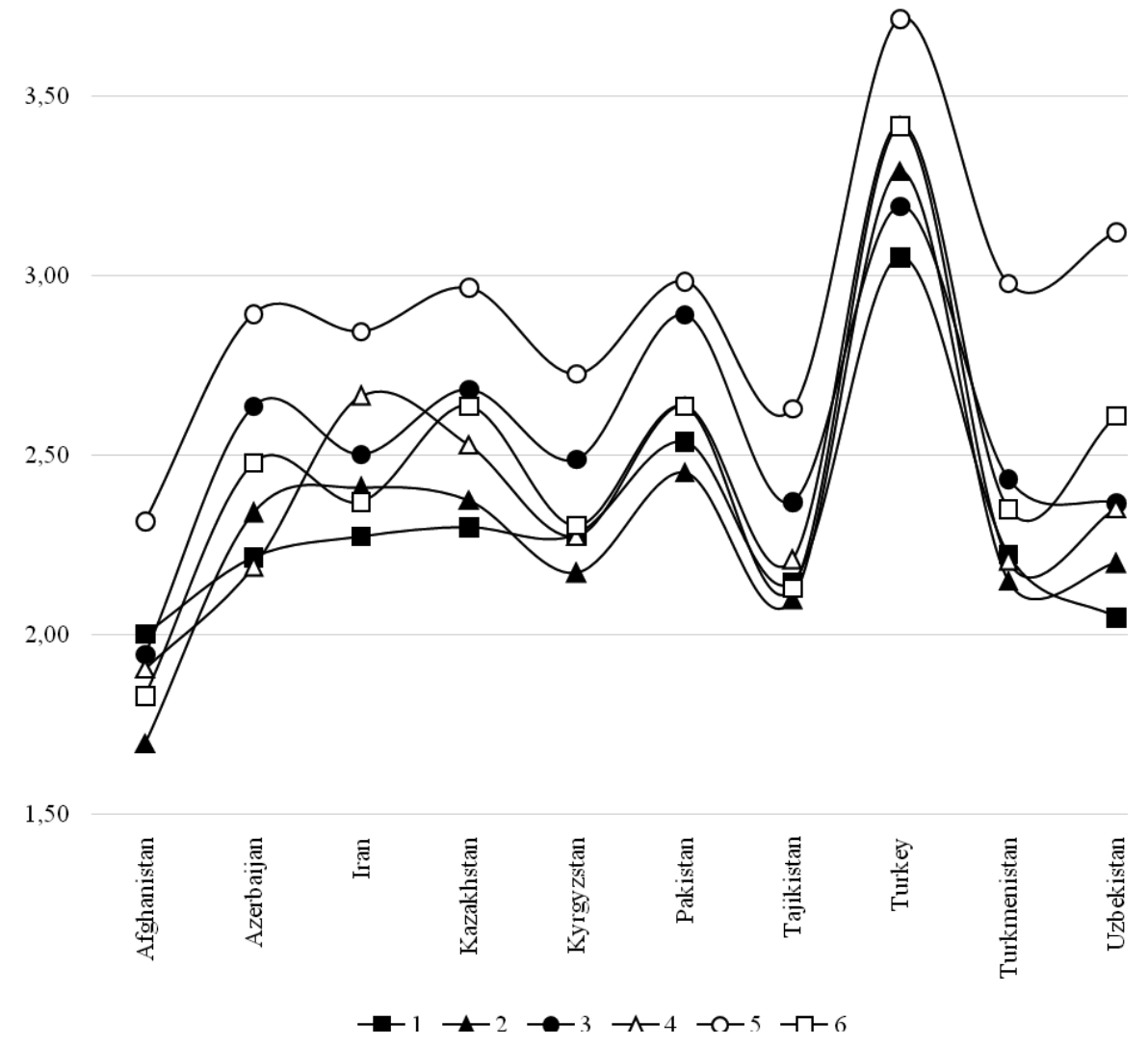

Fig. 8. Average characteristics by each of the 6 efficiency indexes of transport logistics.Source: created by authors after [11] 


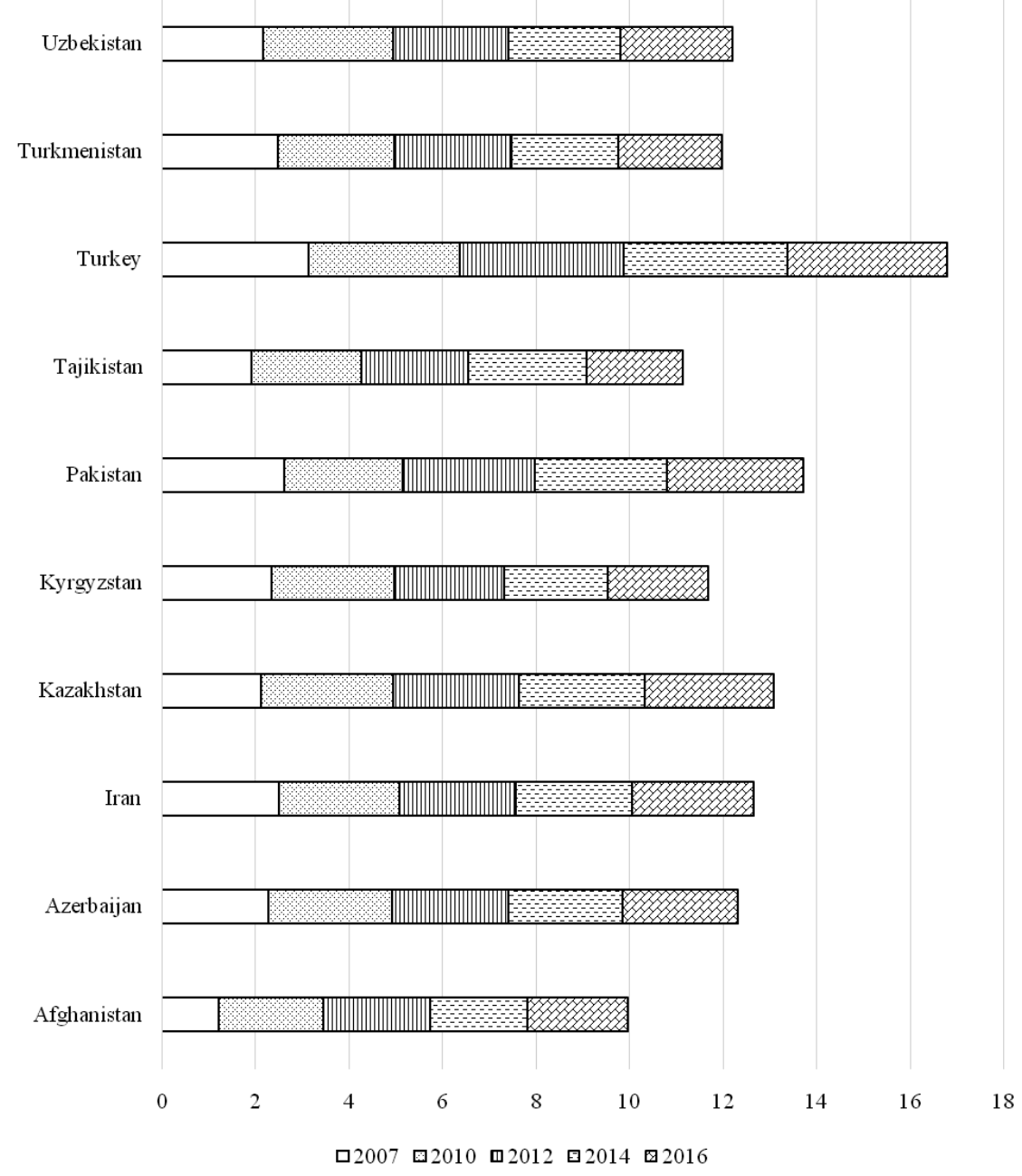

Fig. 9. Dynamics of changes of overall index of transport logistics efficiency in the ECO countries.Source: created by authors after [11]

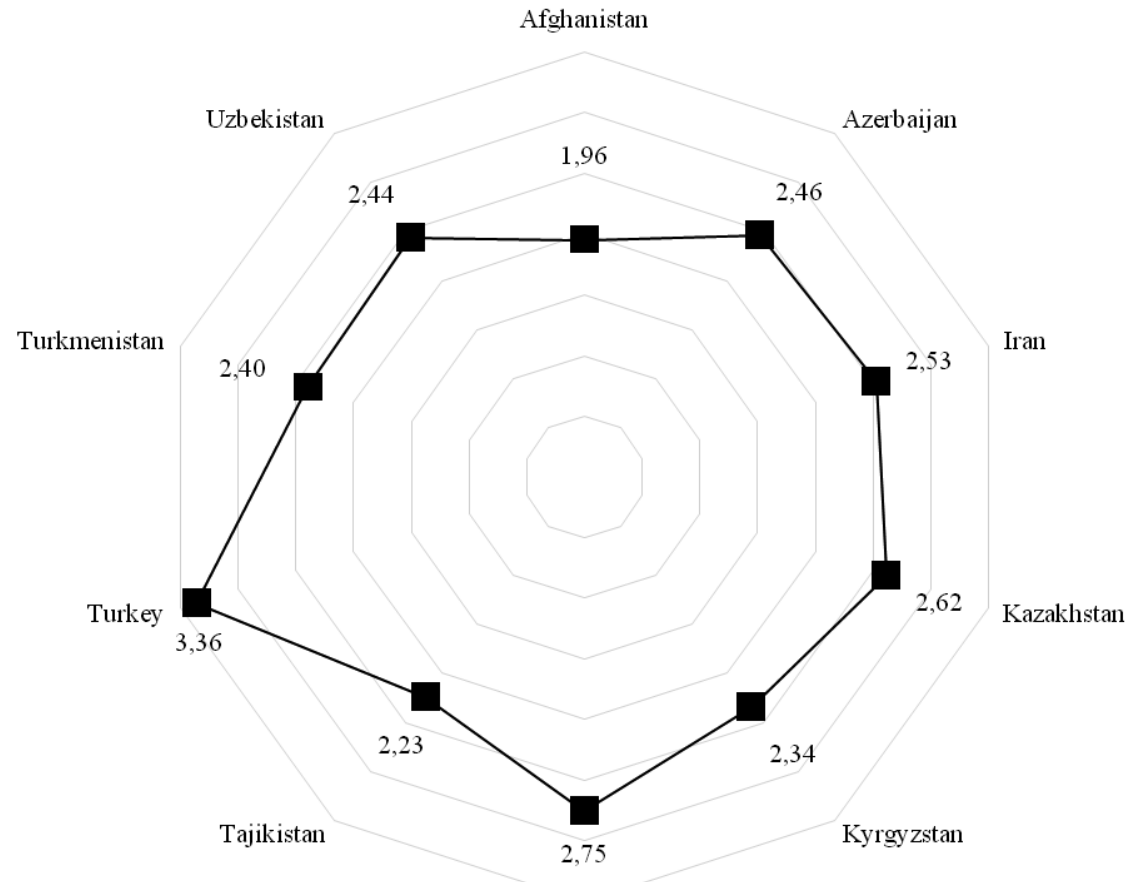

Pakistan

Fig. 10. Average numbers of overall index of transport logistics efficiency. Source: created by authors after [11] 
6. Quality of trade and transport infrastructure $(1=$ low to $5=$ high).

In the Fig.8average characteristicshave been provided (within the studied period of 2007 - 2016) by each of the 6 efficiency indexes of transport logistics.

According to the data in Fig. 8the most efficient transport logistics can be observed in Turkey. Regarding the component structure all the considered countries show the best level of development of component 6 of efficiency index of transport logistics, that is the frequency of planned or expected time cargo delivery to the recipient.

7. Overall index of logistics efficiencyand its dynamic changes within the period of 2007 through 2016 have been provided in the Fig. 9.

In the Fig. 10 average numbers of overall index of transport logistics efficiency have been provided within the studied period of 2007 - 2016 concerning every country of the ECO.

As one can see in the Fig.10Turkey differentiates itself by the level of transport logistics development. The worst level of transport infrastructure functioning via index of transport logistics efficiency can be observed in Turkmenistan and Afghanistan.

Conclusion. Thus, the conducted research has provided an opportunity to assess the contemporary condition of transport infrastructure development in the ECO countries and define that the highest level oftransport infrastructure provision in the ECO countries can be observed inAzerbaijan, Kazakhstan and Turkmenistan, the lowest level of provision can be observed in Kyrgyzstan, Tajikistan and Pakistan; the highest density of road traffic routes can be seenin Turkey and Pakistan. Such countries as Turkmenistan, Kazakhstan and Kyrgyzstan do not have dense road traffic route system; the highest level of passenger turnover is provided by Turkey, all the other countries have 10 times lower volume of passenger traffic by air transport. Analysis of efficiency of transport infrastructure usage has proved that Turkey stands out for the level of transport logistics development. The lowest level of transport infrastructure functioning via index of logistics efficiency can be seen in Turkmenistan and Afghanistan.

\section{References:}

1. ECO's official website.URL: http://www.ecosecretariat.org (date of treatment: 11.12.2017).

2. Рибчук А.В. Проблеми розвитку міжнародної виробничої інфраструктури в умовах глобалізації. URL: http://tourlib. net/statti_others/rybchuk2.htm (date of treatment: 11.12.2017).

3. Коновалова Н.А. Международные транспортные тарифы. М.: Транспорт, 1985. 279 с.

4. Ткаченко Н. Ю. Транспортна інфраструктура: сутність, функції та роль у забезпеченні економічних процесів. Вісник АонАУ- ЕТ. Сер. Екон. науки, 2006. №4 (32). С.56-61.

5. Статистичний сегрегатор по країнах світу. URL:http://knoema.ru (date of treatment: 11.12.2017).

6. Юрченко С.А. Инфраструктура мира: учебное пособие. Х.: ХНУ имени В.Н. Каразина, 2006. 328 с.

7. Маергойз И.М. Методика мелкомасштабных экономико-географических исследований. М: МГУ, 1981. 137 с.

8. Олійник Я.Б. Міжнародна логістика: навч.посібник. К.: Обрії, 2011. 544 с.

9. Смирнов І.Г. Аогістика: просторово-територіальний вимір: монографія. К.: Обрії, 2004. 335 с.

10. Смирнов І.Г. Транспортна логістика: навч. посібник. К.: ЦУА, 2008. 224 с.

11. Full LPI Dataset: 2007, 2010, 2012, 2014, 2016. URL: http://lpi.worldbank.org/report (date of treatment: 11.12.2017). 